\title{
Expert System to Diagnose Malaria With Bayes Method
}

\author{
Mei Melan Rut Sartika Hutapea ${ }^{1}$, R.Mahdalena Simanjorang ${ }^{2}$ \\ 1.2Informatics Engineering Study Program, STMIK Pelita Nusantara, J1.Iskandar Muda No. 1 \\ Medan, North Sumatra, Indonesia 20154 \\ Email:mey.lanchihutapea@gmail.com
}

\begin{abstract}
Malaria is a deadly disease. The disease is caused by a virus that is transmitted through the bite plasmadium Anopheles mosquito tropics. , Indonesia is an area that has a tropical climate so that malaria prevalent in Indonesia. Many public cloud lack of knowledge about the symptoms of malaria because malaria disease symptoms similar to the usual feverish illness. If the disease is not handled seriously can lead to death. From the above explanation makes the excuse needed one expert system that can help people diagnose malaria by looking at symptoms, and later this expert system can explain and diagnose whether a disease malaria or not. In the expert system there are several methods used to menagani a problem. With the solution given institute Bayes Method in helping to diagnose diseases, the expert system that can help people diagnose malaria by looking at symptoms, and later this expert system can explain and diagnose whether a disease malaria or not. Expert System is generally defined as a system that is able to region contribute to solving or handling problems. Expert System is not intended to replace the expert, but to help and support experts. Bayesian methods can diagnose simple encoding and faster calculation. expert system that can help people diagnose malaria by looking at symptoms, and later this expert system can explain and diagnose whether a disease malaria or not. Expert System is generally defined as a system that is able to region contribute to solving or handling problems. Expert System is not intended to replace the expert, but to help and support experts. Bayesian methods can diagnose simple encoding and faster calculation. expert system that can help people diagnose malaria by looking at symptoms, and later this expert system can explain and diagnose whether a disease malaria or not. Expert System is generally defined as a system that is able to region contribute to solving or handling problems. Expert System is not intended to replace the expert, but to help and support experts. Bayesian methods can diagnose simple encoding and faster calculation. Expert System is generally defined as a system that is able to region contribute to solving or handling problems. Expert System is not intended to replace the expert, but to help and support experts. Bayesian methods can diagnose simple encoding and faster calculation. Expert System is generally defined as a system that is able to region contribute to solving or handling problems. Expert System is not intended to replace the expert, but to help and support experts. Bayesian methods can diagnose simple encoding and faster calculation.
\end{abstract}

Keywords: Malaria, Bayes, Expert System.

\section{Introduction}

Integrated system in the computer has been able to store large amounts of data, and search data stored in a short time even nowadays computers have become tools in decision-making man. One branch of computer science that many human uses in helping it works is the Expert System which is one branch of Artificial Intelligence or Artificial Intelligence (AL) are trying to adopt human knowledge into a computer so that the computer can resolve the issue as was done by expert, expert system is the main application of artificial intelligence the most widespread applicability. An expert system has been widely applied in various fields. One is in the field of medicine or health. Implementation of expert systems in the field of health can be kedoteran or diagnosis of disease, disease consultation, and even up to the solution of existing disease diagnosis. Malaria is a deadly disease. The disease is caused by a virus that is transmitted through the bite plasmadium nyamukAnopheles temperate tropis.Indonesia is an area that has a tropical climate so that malaria prevalent in Indonesia. Many public cloud lack of knowledge about the symptoms of malaria because malaria disease symptoms similar to the usual feverish illness. If the disease is not handled seriously can lead to death. Malaria is a deadly disease. The disease is caused by a virus that is transmitted through the bite plasmadium nyamukAnopheles temperate tropis.Indonesia is an area that has a tropical climate so that malaria prevalent in Indonesia. Many public cloud lack of knowledge about the symptoms of malaria because malaria disease symptoms similar to the usual feverish illness. If the disease is not handled seriously can lead to death. Malaria is a deadly disease. The disease is caused by a virus that is transmitted through the bite plasmadium nyamukAnopheles temperate tropis.Indonesia is an area that has a tropical climate so that malaria prevalent in Indonesia. Many public cloud lack of knowledge about the symptoms of malaria because malaria disease symptoms similar to the usual feverish illness. If the disease is not handled seriously can lead to death. Many public cloud lack of knowledge about the symptoms of malaria because malaria disease symptoms similar to the usual feverish illness. If the disease is not handled seriously can lead to death. Many public cloud lack of 
knowledge about the symptoms of malaria because malaria disease symptoms similar to the usual feverish illness. If the disease is not handled seriously can lead to death.

In this study metodesatu expert system that can help people diagnose malaria by looking at symptoms, and later this expert system can explain and diagnose whether a disease malaria or not. In the expert system there are several methods used to menagani a problem. Several methods have been used such as fuzzy logic, Forward Chaining and others. In this study using Bayes methods. Bayesian methods is one branch of mathematical theory maybe we have to make a model of the uncertainty of an event by combining the common knowledge of the fact observations. Bayesian methods has advantages compared to other methods that Bayesian methods more easily understood,

\section{Theory}

\subsection{Expert system}

According to Turban and Aronson (2001: 3) describes the expert system is a system that is trying to adopt human knowledge into a computer designed for modeling ability to solve problems like an expert.

\section{2 methods Bays}

According to Sri Hartati and Sari Iswanti (2008: 70) explains the Bayesian probability is one to cope with uncertainty by Bayes formula dikemukan bayesteorema first by a priest Prebyterian England, in 1763 named Thomas Bayes, who later perfected by Laplace. Bayes theorem is used to calculate the probability of occurrence of an event based on the effect obtained from the observation. Besides, Bayes theorem utilize data obtained from population samples also consider an initial distribution of the so-called Prior. The general shape theorem can be seen in the following equation:

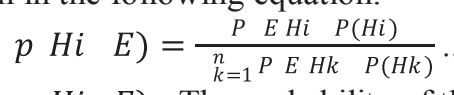

$p H i \quad E)=$ The probability of the hypothesis $\mathrm{H} 2$ true if given evidace $\mathrm{E}$

$p H i \quad H 2)=$ Probabiltas

$P(E \mid H 2)$ The probability of the hypothesis Hi (according to the results of any evidana next to be looked at). If after panyajian against the hypothesis appears one or more evidance then can use the following equation.

$P H i \quad E) \frac{P \quad E H i \otimes P(H i)}{n_{k=1}^{n} P E, E \ldots E H K \otimes P(H k)}$.....

\section{Research methods}

The method used in this study are:

a. Idetifikasi issue, problem identification stage needs to be done to diagnose malaria For problems can only be done by an expert or a doctor alone and Need for an expert system in order to facilitate the public to mendiangnosa malaria.Belum disease designing the expert system to diagnose malaria.

b. Data collection, There are several techniques for data collection, namely Interview (Interview) Prior to the application development process, the researchers first conducted interviews with relevant parties. This interview was conducted by way of question and answer directly to those who can provide the necessary information about the data of malaria as well as the symptoms, and prevention solutions.

c. Implementation phase is the last stage of perancagan a system generated as for the implementation of the system in this case is the user interface (interface). As for the user interface (interface)

\section{Results and Discussion}

Methods that researchers use in the writing of this expert system is the method of Bayes. After all symptom data, the data type of the disease and the probability value. So by using Bayes methods there are several steps or stages of data Bayes method:

1) Reading Data Training

a. $\quad$ Malaria tertian $=\mathrm{P} 01$

$\mathrm{G} 01=\mathrm{P}(\mathrm{E} \mid \mathrm{H} 1)=0.3$

$\mathrm{G} 02=\mathrm{P}(\mathrm{E} \mid \mathrm{H} 1)=0.3$

$\mathrm{G} 14=\mathrm{P}(\mathrm{E} \mid \mathrm{H} 1)=0.5$

$\mathrm{G} 10=\mathrm{P}(\mathrm{E} \mid \mathrm{H} 1)=0.4$

$\mathrm{G} 08=\mathrm{P}(\mathrm{E} \mid \mathrm{H} 1)=0.7$

$\mathrm{G} 05=\mathrm{P}(\mathrm{E} \mid \mathrm{H} 1)=0.8$ 
b. $\quad$ Malaria Quartina $=\mathrm{P} 02$

$\mathrm{G} 06=\mathrm{P}(\mathrm{E} \mid \mathrm{H} 2)=0.8$

$\mathrm{G} 08=\mathrm{P}(\mathrm{E} \mid \mathrm{H} 2)=0.7$

$\mathrm{G} 03=\mathrm{P}(\mathrm{E} \mid \mathrm{H} 2)=0.2$

$\mathrm{G} 01=\mathrm{P}(\mathrm{E} \mid \mathrm{H} 2)=0.3$

$\mathrm{G} 02=\mathrm{P}(\mathrm{E} \mid \mathrm{H} 2)=0.3$

$\mathrm{G} 12=\mathrm{P}(\mathrm{E} \mid \mathrm{H} 2)=0.6$

$\mathrm{G} 04=\mathrm{P}(\mathrm{E} \mid \mathrm{H} 2)=0.4$

c. Malaria tropicana $=\mathrm{P} 03$

$\mathrm{G} 04=\mathrm{P}(\mathrm{E} \mid \mathrm{H} 3)=0.4$

$\mathrm{G} 07=\mathrm{P}(\mathrm{E} \mid \mathrm{H} 3)=0.8$

$\mathrm{G} 13=\mathrm{P}(\mathrm{E} \mid \mathrm{H} 3)=0.4$

$\mathrm{G} 08=\mathrm{P}(\mathrm{E} \mid \mathrm{H} 3)=0.7$

$\mathrm{G} 01=\mathrm{P}(\mathrm{E} \mid \mathrm{H} 3)=0.3$

$\mathrm{G} 14=\mathrm{P}(\mathrm{E} \mid \mathrm{H} 3)=0.5$

$\mathrm{G} 02=\mathrm{P}(\mathrm{E} \mid \mathrm{H} 3)=0.3$

$\mathrm{G} 03=\mathrm{P}(\mathrm{E} \mid \mathrm{H} 3)=0.2$

$\mathrm{G} 11=\mathrm{P}(\mathrm{E} \mid \mathrm{H} 3)=0.5$

2) Summing the probabilities of each evidance value for each hypothesis based on the data samples.

$$
=P E H k=G 1+G 2+\otimes G n
$$

a. $\quad$ Malaria tertian $=\mathrm{P} 01$

$$
k=n
$$

$n$

$$
=0,3+0,3+0,5+0,4+0,7+0,8=3,0
$$

b. Malaria Quartina $=\mathrm{P} 02$

$$
=0,8+0,7+0,2+0,3+0,3+0,6+0,4=3,3
$$

$k=n$
c. $\quad$ Malaria tropicana $=\mathrm{P} 02$

$$
{ }_{k=n}^{n}=0,4+0,8+0,4+0,7+0,3+0,5+0,3+0,2+0,5=4.1
$$

3) Finding the value of the probability of the hypothesis $\mathrm{H}$ regardless of any evidance again for each.

a. $\quad$ Malaria tertian $=\mathrm{P} 01$

$$
\mathrm{P}(\mathrm{Hi})=\frac{P(E \mid H i)}{k_{k=n}^{n} \mathrm{P}(\mathrm{E} \mid \mathrm{Hk})}
$$

$$
\begin{aligned}
\mathrm{G} 01 & =\mathrm{P}(\mathrm{H} 1)=\frac{0,3}{3}=0,10 \\
\mathrm{G} 02 & =\mathrm{P}(\mathrm{H} 1)=\frac{0,3}{3}=0,10 \\
\mathrm{G} 14 & =\mathrm{P}(\mathrm{H} 1)=\frac{0,5}{3}=0,16 \\
\mathrm{G} 10 & =\mathrm{P}(\mathrm{H} 1)=\frac{0,4}{3}=0,13 \\
\mathrm{G} 08 & =\mathrm{P}(\mathrm{H} 1)=\frac{0,7}{3}=0,23 \\
\mathrm{G} 05 & =\mathrm{P}(\mathrm{H} 1)=\frac{0,8}{3}=0,26
\end{aligned}
$$

b. Malaria Quartina $=\mathrm{P} 02$

$$
\begin{aligned}
& \mathrm{G} 06=\mathrm{P}(\mathrm{H} 2) \frac{0,8}{3,3}=0,24 \\
& \mathrm{G} 08=\mathrm{P}(\mathrm{H} 2) \frac{0,7}{3,3}=0,21 \\
& \mathrm{G} 03=\mathrm{P}(\mathrm{H} 2)=\frac{0,2}{3,3}=0,06 \\
& \mathrm{G} 01=\mathrm{P}(\mathrm{H} 2)=\frac{0,3}{3,3}=0,09 \\
& \mathrm{G} 02=\mathrm{P}(\mathrm{H} 2)=\frac{0,3}{3,3}=0,09 \\
& \mathrm{G} 12=\mathrm{P}(\mathrm{H} 2)=\frac{0,6}{3,3}=0,18 \\
& \mathrm{G} 04=\mathrm{P}(\mathrm{H} 2)=\frac{0,4}{3,3}=0,12
\end{aligned}
$$

c. $\quad$ Malaria tropicana $=\mathrm{P} 03$ 


$$
\begin{aligned}
& \mathrm{G} 04=\mathrm{P}(\mathrm{H} 3)=\frac{0,4}{4,1}=0,09 \\
& \mathrm{G} 07=\mathrm{P}(\mathrm{H} 3)=\frac{0,8}{4,1}=0,19 \\
& \mathrm{G} 13=\mathrm{P}(\mathrm{H} 3)=\frac{0,4}{4,1}=0,09 \\
& \mathrm{G} 08=\mathrm{P}(\mathrm{H} 3)=\frac{0,7}{4,1}=0,17 \\
& \mathrm{G} 01=\mathrm{P}(\mathrm{H} 3)=\frac{0,3}{4,1}=0,07 \\
& \mathrm{G} 14=\mathrm{P}(\mathrm{H} 3)=\frac{0,5}{4,1}=0,12 \\
& \mathrm{G} 02=\mathrm{P}(\mathrm{H} 3)=\frac{0,3}{4,1}=0,07 \\
& \mathrm{G} 03=\mathrm{P}(\mathrm{H} 3)=\frac{0,2}{4,1}=0,04 \\
& \mathrm{G} 11=\mathrm{P}(\mathrm{H} 3)=\frac{0,5}{4,1}=0.12
\end{aligned}
$$

4) Finding the value of the probability of the hypothesis looked evidance by making a probability value evidance with a probability value regardless evidance hypothesis and summing the multiplication results for each hypothesis.

a. Malaria tertian $=\mathrm{P} 01$

$$
\begin{aligned}
& \stackrel{n}{k=n}=0,3 \times 0,10+0,3 \times 0,10+0,5 \times 0,16+0,4 \times 0,13+0,7 \times 0,23+ \\
& 0,8 \times 0,26=0,03+0,03+0,08+0,05+0,16+0,20=0.5
\end{aligned}
$$

b. Malaria quartiana $=\mathrm{P} 02$

$$
\begin{aligned}
& \stackrel{n}{k=n}=0,8 \times 0,24+0,7 \times 0,21+0,2 \times 0,06+0,3 \times 0,09+0,3 \times 0,09+0,6 \times 0,18+ \\
& (0,4 \times 0,12) \\
& =0.19+0.14+0.01+0.02+0.02+0.10+0.04 \\
& =0.52
\end{aligned}
$$

c. Malaria tropicana $=\mathrm{P} 03$

$$
\begin{aligned}
& \stackrel{n}{k=n}=0,4 \times 0,09+0,8 \times 0,19+0,4 \times 0,09+0,7 \times 0,17+0,3 \times 0,07+0,5 \times 0,12+ \\
& 0,3 \times 0,07+(0,2 \times 0,04)+(0,5 \times 0,12) \\
= & 0.03+0.15+0.03+0.11+0.02+0.06+0.02+0.008+0.06 \\
= & 0.48
\end{aligned}
$$

5) Finding the value of $\mathrm{P}(\mathrm{Hi} \mid \mathrm{E})$ or the probability of the hypothesis $\mathrm{Hi}$ is true if given evidance $\mathrm{E}$.

a. Malaria tertian $=\mathrm{P} 01$

$$
P \mathrm{Hi} \mid E i=\frac{\mathrm{P} \text { E Hi } \otimes \mathrm{P}(\mathrm{Hi})}{{ }_{k=n}^{n} \mathrm{P}(\mathrm{E} \mid \mathrm{HK})}
$$

$$
\begin{aligned}
& \mathrm{P}(\mathrm{H} 1 \mid \mathrm{E} 1)=\frac{0,3 \times 0,03}{0,55}=0,16 \\
& \mathrm{P}(\mathrm{H} 1 \mid \mathrm{E} 1)=\frac{0,3 \times 0,03}{0,55}=0,16 \\
& \mathrm{P}(\mathrm{H} 1 \mid \mathrm{E} 1)=\frac{0,5 \times 0,08}{0,55}=0,072 \\
& \mathrm{P}(\mathrm{H} 1 \mid \mathrm{E} 1)=\frac{0,4 \times 0,05}{0,55}=0,036 \\
& \mathrm{P}(\mathrm{H} 1 \mid \mathrm{E} 1)=\frac{0,7 \times 0,16}{0,55}=0,206 \\
& \mathrm{P}(\mathrm{H} 1 \mid \mathrm{E} 1)=\frac{0,8 \times 0,20}{0,55}=0,29
\end{aligned}
$$

b. Malaria Quartina $=\mathrm{P} 02$

$$
\begin{aligned}
& \mathrm{P}(\mathrm{H} 2 \mid \mathrm{E} 2)=\frac{0,8 \times 0,19}{0,52}=0,29 \\
& \mathrm{P}(\mathrm{H} 2 \mathrm{E} 2)=\frac{0,7 \times 0,14}{0,52}=0,18 \\
& \mathrm{P}(\mathrm{H} 2 \mid \mathrm{E} 2)=\frac{0,2 \times 0,01}{0,52}=0,003 \\
& \mathrm{P}(\mathrm{H} 2 \mid \mathrm{E} 2)=\frac{0,2 \times 0,02}{0,52}=0,011 \\
& \mathrm{P}(\mathrm{H} 2 \mid \mathrm{E} 2)=\frac{0,3 \times 0,02}{0,52}=0,011 \\
& \mathrm{P}(\mathrm{H} 2 \mid \mathrm{E} 2)=\frac{0,6 \times 0,10}{0,52}=0,11 \\
& \mathrm{P}(\mathrm{H} 2 \mid \mathrm{E} 2)=\frac{0,4 \times 0,04}{0,52}=0,03
\end{aligned}
$$

c. Malaria tropicana $=\mathrm{P} 03$

$$
\mathrm{P}(\mathrm{H} 3 \mid \mathrm{E} 3)=0.025 \frac{0,4 \times 0,03}{0,48}=
$$




$$
\begin{aligned}
& \mathrm{P}(\mathrm{H} 3 \mid \mathrm{E} 3)=0.25 \frac{0,8 \times 0,15}{0,48}= \\
& \mathrm{P}(\mathrm{H} 3 \mid \mathrm{E} 3)=0.025 \frac{0,4 \times 0,03}{0,48}= \\
& \mathrm{P}(\mathrm{H} 3 \mid \mathrm{E} 3)=0.16 \frac{0,7 \times 0,11}{0,48}= \\
& \mathrm{P}(\mathrm{H} 3 \mid \mathrm{E} 3)=0.0125 \frac{0,3 \times 0,02}{0,48}= \\
& \mathrm{P}(\mathrm{H} 3 \mid \mathrm{E} 3)=0.0625 \frac{0,5 \times 0,06}{0,48}= \\
& \mathrm{P}(\mathrm{H} 3 \mid \mathrm{E} 3)=0.0125 \frac{0,3 \times 0,02}{0,48}= \\
& \mathrm{P}(\mathrm{H} 3 \mid \mathrm{E} 3)=\frac{0,2 \times 0,008}{0,48}=0,003 \\
& \mathrm{P}(\mathrm{H} 3 \mid \mathrm{E} 3)=0.0625 \frac{0,5 \times 0,06}{0,48}=
\end{aligned}
$$

6) Finding the value of the conclusions of teoreman Bayes by transferring value to the beginning or evidance probability $\mathrm{P}(\mathrm{E} \mid \mathrm{Hi}$ ) with the hypothesis $\mathrm{Hi}$ is true if given evidance $\mathrm{E}$ or $\mathrm{P}(\mathrm{Hi} \mid \mathrm{E})$ and summing the results of multiplication.

a. malaria tertian

$$
\underset{k=n}{n} \text { bayes }=\mathrm{P}(\mathrm{E} \mid \mathrm{H} 1) * \mathrm{P}(\mathrm{E} 1 \mid \mathrm{H} 1)+\ldots+\mathrm{P}(\mathrm{E} \mid \mathrm{Hi}) * \mathrm{P}(\mathrm{E} \mid \mathrm{Hi})
$$

$$
\begin{aligned}
& \stackrel{n}{k=n} 0,3 \times 0,016+0,3 \times 0,016+(0,5 \times 0,072)+(0,4 \times 0,036)+(0,7 \times 0,206)+(0,8 \times 0,29) \\
= & 0.0048+0.0042+0.036+0.014+0.14+0.23 \\
= & 0.429 \times 100 \%=42.9 \%
\end{aligned}
$$

b. malaria quartiana

$$
\begin{aligned}
& \stackrel{n}{k=n} 0,8 \times 0,29+0,7 \times 0,18+0,2 \times 0,003+0,3 \times 0,011+(0,2 \times 0,011)+(0,6 \times 0,11)+(0,4 \times 0,03) \\
& =0.16+0.126+0.0006+0.0033+0.066+0.012 \\
& =0.3712 \times 100 \%=37.12 \%
\end{aligned}
$$

c. malaria tropicana

$$
\begin{aligned}
& \stackrel{n}{k=n} 0,4 \times 0,25+, 87 \times 0,25+0,4 \times 0,025+0,7 \times 0,11+(0,3 \times 0,0125)+(0,5 \times 0,0625)+ \\
& (0,3 \times 0,0125)+(0,2 \times 0,008)+(0,5 \times 0,0625) \\
& =0.01+0.2+0.01+0.077+0.0037+0.031+0.0037+0.0016+0.031 \\
& =0.368 \times 100 \%=36.8 \%
\end{aligned}
$$

\section{Conclusion}

Based on the discussion regarding Diagnosing malaria with Bayes method it can be concluded:

a. The application of this expert system uses Bayesian methods measuring tinggat certainty on tuberculosis.

b. With the web-based application will facilitate the public to access information about malaria early without having to go to the hospital first

c. Applications are made to produce output name the types of malaria, the symptoms of malaria as well as the percentage of diagnosis of the disease.

\section{Reference}

[1] Amina Hendini, 2016 .Pemodelan UML Sale of Goods Monitoring Information System (Case Study: Distro Zhezia Pontianak). Journal of Information Equator.

[2] Ade Suryanto, 2016. Design Build Artist Registration Information System Based on WEB Using Waterfall Model (Case Study: Team Management Agency) Journal Equator Informatics.

[3] Doro Edi, Stevalin Betshani, 2009. Data Analysis System Using Conceptual Data Model ERD And warehous. Journal InformatikaVol.5. Number 1.

[4] Eka Wida Fridayanthie 2016. Draft ATK Bnagun sisem Perintaan Information-Based Intranet. Journal of Information Equator.

[5] Hersatoto 2008. Meranang And Making Expert System. Journal of Dynamic Information Technology

[6] Ibn Akil. Software Engineering With Unified Model Prosecess. Pilar Nusa Mandiri Journal Vol. XII, 1.

[7] Rusdiyanto 2018. Due Disease Diagnosis Expert System Mosquito Bites With Web Based Bayes Method. Jutim, Vol 3 No.1.

[8] Sriyadi, Nurhasanah, Taufik Baidawi 2018. Diagnose Disease Expert System Using Web-Based Tilapia Forward Chaining method. Journal of Computer and Information Technology, Paradigm.

[9] Sri Hartati, Sri Iswanti 2018. Expert Sist. Yogyakarta: Graha Science

[10] Yossi Octavina, Abdul Fadlil. Expert System to Diagnose Disease In Pernafasa And Lung Channel Cerainty Method Using Factor. Bachelor of Engineering Informatics Journal Vol 2 \# 2. 